\title{
Donkey's Story: A Study on the Changes of Ecology, Economy and Culture Based on the Change of Donkey Populations of Four Communities in Central TAR
}

\author{
Yang Weiwei ${ }^{1}$, Liu Yinghua ${ }^{2}$, Luorong Zhandui ${ }^{3}$ \\ ${ }^{1}$ School of Economics and Management, Beijing University of Technology, Beijing, China \\ ${ }^{2}$ Institute of Sociology and Economics, Chinese Center of Tibetology, Beijing, China \\ ${ }^{3}$ Sichuan University, Chengdu, China \\ Email: janeyang99@hotmail.com, shanpoy@aliyun.com, mssthy@gmail.com
}

Received August 23 ${ }^{\text {rd }}$, 2013; revised September 25 $5^{\text {th }}$, 2013; accepted October $4^{\text {th }}, 2013$

\begin{abstract}
Copyright ( 2013 Yang Weiwei et al. This is an open access article distributed under the Creative Commons Attribution License, which permits unrestricted use, distribution, and reproduction in any medium, provided the original work is properly cited.
\end{abstract}

\begin{abstract}
Based on long time field study in Tibetan communities in central Tibet Autonomous Region (TAR) and empirical knowledge, through analyzing the population change of donkeys of different communities, this article aims at finding the reasons of the changes caused by economic and social changes, especially changes in eco-environment, in order to provide a perspective to better understand changes in TAR.
\end{abstract}

Keywords: Tibetan Community; Donkey Populations; Environmental and Social Change

\section{Introduction}

Livestock are important producing and living materials for Tibetan farmers and herdsmen. Even in the relatively developed farming area by the river valley, which has been appointed by the government as commercial foodstuff production base, there are no farmers who never engage in animal husbandry. Through animal husbandry, farmers obtain ghee and dejecta, two important nutrition sources for both people and farming land, with dejecta as a major energy source. They also get fur and feather, raw materials for cold-defense. Therefore, animal husbandry (Luorong Zhandui 罗线战堆, 2006) in Tibetan rural areas plays a vital role in agricultural development and livelihood improvement, so the complementation of agriculture and farmers (Luorong Zhandui 罗线战堆, 2009) is the foundation and basic rule of Tibetan rural economic development.

After 1984, the Tibet Autonomous Region performed a great reform in operation right and ownership right of major producing material, i.e. distributing farming land and livestock to farmers and guaranteeing the consistency of this policy. The ownership right of farming land did not entirely belong to farmers, who merely have use right, but the property right of livestock was completely given to farmers so they could manage their cattle freely. Thus, farmers' preferences to livestock were mainly determined by environment, need and traditional culture, and the government did not virtually interfere. A study of this issue can help to conclude factors contributing to farmers' preferences to their animal-breeding.

Since 1996, the authors have followed the development of rural animal husbandry of four communities in middle Tibet, including Village Zhaxilin, Village Chabalang, Village Cundui and Village Lunbugang. What has impressed us most is donkey, an animal usually receiving little attention. But it is hard to find related statistics, and harder to search for previous research on donkeys. Therefore, the research on the donkey, an obscure object, has new value and may lead to new conclusions.

\section{Change in Number of Donkeys and Stories about History, Ecology and Economy}

\section{Retrospect of the Number and Uses of Donkeys}

Tibet, located in Qinghai-Tibet Plateau, used to be an inaccessible area. Although the producing and living conditions as well as infrastructure have been greatly improved, Tibet on the whole is still a society with profound traditional culture and self-sufficient economy (Luorong Zhandui 罗线战堆, 1996). In this sense, farmers' preferences to livestock and other economic activities must have strong succession. The following is a brief introduction to Tibetan democratic reforms dating from 1959, the population as well as the number (see Table 1) and major uses of donkeys.

What requires further explanation is: before the democratic reform in 1959 , over $80 \%$ donkeys in the four communities belonged to several "chaiba". Most farmers were tenants or even "langsheng" (with no freedom) attached to different chaiba. Also, the main uses of donkeys before 1959 could be summarized into the following three aspects:

- Donkeys were a major transport tool for farmers to do their corvee.

Before 1959, nearly all farming land in Village Zhaxilin, Village Chabalang and Village Cundui was almost possessed by three temples in Tibet, and farmers had to bear heavy corvee. Farmers not only had to pay ground rent to temples even $100 \mathrm{li}$ away, but also had to complete. Some older people recalled that back then modern transport tools and roads were not available, donkeys were the best livestock for long-distance transport. 
Table 1.

Population of residents and donkeys in the 4 communities in 1959.

\begin{tabular}{|c|c|c|c|c|c|c|}
\hline & $\begin{array}{l}\text { Population, } \\
\text { households, } \\
\text { donkeys }\end{array}$ & $\begin{array}{l}\text { Village } \\
\text { Zhaxilin }\end{array}$ & $\begin{array}{c}\text { Village } \\
\text { Chabalang }\end{array}$ & $\begin{array}{l}\text { Village } \\
\text { Cundui }\end{array}$ & $\begin{array}{l}\text { Village } \\
\text { Lunbugang }\end{array}$ & Total \\
\hline \multirow{3}{*}{$\begin{array}{l}\text { 岁 } \\
\stackrel{\Xi}{\Xi}\end{array}$} & $\begin{array}{l}\text { Population } \\
\text { (unit: person) }\end{array}$ & 350 & 97 & 200 & 110 & 757 \\
\hline & $\begin{array}{l}\text { Households } \\
\text { (unit: } \\
\text { household) }\end{array}$ & 45 & 19 & 30 & 27 & 121 \\
\hline & $\begin{array}{c}\text { Donkeys } \\
\text { (unit: donkey) }\end{array}$ & 25 & 50 & 35 & 0 & 110 \\
\hline
\end{tabular}

Note: Source: the authors’ field work in 1996.

- Donkeys were the major transport tool for farmers to cut firewood.

Firewood is the most important producing material for Tibetan farmers. Though livestock dejecta was the most widely used fuel, it could not meet the need. Farmers also needed to cut bushes and plants from the mountains to make fire and fry hulless barley. Additionally, most Tibetan farmers believe in Tibetan Buddhism, and they do "weisang" every day as a form of religious ritual, for which Chamaecyparis obtuse, capitate rhododendron branchlet and leaf, as well as pine and cypress would be cut down in farther mountains and then transported back. Because of the remoteness and rough roads, the donkey, as an assiduous animal good at walking in mountainous areas, became the best transport tool for farmers.

- Donkeys were an important help for agricultural operation.

In old Tibet, lack of agricultural machines, donkeys were the most helpful help for farmer to transport manure and fruit of labor in spring and autumn. In some areas, donkeys also helped to plough and thresh. Besides, the transport of many objects required for farmers' daily production and life would also need donkeys.

\section{Changes in the Number and Uses of Donkeys since 1984}

For most time during 1959-1984, similar to most of Chinese internal areas, rural districts in Tibet set up people's communes under the planned economy. At that time, the production team attached to people's communes was the basic running unit in the countryside, and farmers had no ownership right or operation right of producing materials such as land and livestock.

After 1984, Tibetan farmers obtained the full ownership right and operation right of livestock. Meanwhile, Tibet became more open in every aspect, and market played a more important role in resource allocation. One issue we are concerned with is how farmers chose the breed of their livestock, the factors influencing the farmers' preferences, and the relevant stories, etc. The following table shows the number of population and livestock in the four traditional Tibetan communities in 1984 and 2010, respectively (see Table 2).

The table clearly shows that between 1984 and 2009, the population and households of the 4 communities increased steadily by $26.68 \%$ and $33.3 \%$ respectively. The number of pigs and cattle also grew sharply. The number of pigs, cows, dzhoes and yaks increased by $206.6 \%, 50.8 \%, 68.5 \%$ and $30.8 \%$, respectively. On the contrary, the number of donkeys, sheep and horses decreased to different extents, with $15.38 \%$ for horses,
Table 2.

Population of donkeys in the 4 communities in 1984 and 2010.

\begin{tabular}{cccccc}
\hline Year & $\begin{array}{c}\text { Village } \\
\text { Zhaxilin }\end{array}$ & $\begin{array}{c}\text { Village } \\
\text { Chabalang }\end{array}$ & $\begin{array}{c}\text { Village } \\
\text { Cundui }\end{array}$ & $\begin{array}{c}\text { Village } \\
\text { Lunbugang }\end{array}$ & Total \\
\hline 1984 & 500 & 30 & 180 & 0 & 710 \\
2009 & 2 & 0 & 96 & 0 & 98 \\
\hline
\end{tabular}

Note: Source: the authors' field work in 1984 and 2009.

$17.65 \%$ for sheep and a staggering $624.5 \%$ for donkeys. Below is the analysis of the change of donkey population in different communities and related problems:

First, in Village Lunbugang, Maizhokunggar county, Lhasa city, donkeys are widely used in farming areas and farming-pastoral areas by the river valley. However, this village is an exception: donkeys have never been raised in there. Local farmers, experts at animal husbandry and relevant people did not give accurate answer to this issue. We approach the issue from the following perspectives:

From historical point of view, in old Tibet, Village Lunbugang was controlled by local nobles, and attached tenants and “langsheng” needn’t ride donkeys to handle affairs.

From environmental point of view, this village is situated west to Mila Mountain at the juncture of Linzhi district, with better vegetation than Midwest Tibet. In summer, abundant trees and bush make it unnecessary for farmers to cut firewood in the distance (Nan Wenyuan 南文渊, 2008).

From population point of view, the village is a typical farming-pastoral area and farming land is distributed near cottages, with smaller area and less production. Up to now, horses are enough for essential agricultural activities, so it is not necessary for farmers to keep donkeys.

From cultural point of view, Tibetans consider expensive fur clothing, jewels and the number of cattle as symbol of wealth. Among them, strong horses and yaks, especially female yaks are regarded as major wealth of farmers (Tsering Dundrup 得 荣・泽仁邓珠, 2005), so if they can choose, they usually choose other livestock than donkeys.

Therefore, "being inapplicable" is a possible reason for this and other villages in Maizhokunggar county not to raise donkeys, but not a major one. Luxuriant grass in this area provides a firm ecological foundation for farmers to choose the kind of livestock they prefer, and this is probably the most important reason. A more convincing case is Taba, a community 10 kilometers west of the village. In old Tibet, this community was a base of pottery-making in Middle Tibet. Nobles lived in Lhasa and monks in the temple often used pottery produced here. Local farmers needed to do much corvee about pottery. This village is nearly 80 kilometers away from Lhasa. They had to do much corvee to produce pottery. In other areas of Tibet, donkeys are bound to be the major transport tool, but they have never been bred in this village. This village is only responsible for production, while transport is in the charge of farmers in Dazi county. According to a senior technician in charge of pottery in old Tibet, “qimo", at that time, if green pottery was sent to Lhasa, horses covered with brilliant clothes would be used. This showed that donkeys as livestock for the poor seemed less likely to appear in this village. Therefore, it was reasonable, historically and culturally, even for the local poor to, if possible, raise horses instead of donkeys.

The change in number of donkeys and their stories in the other three communities after 1984 are worth exploring. 
Table 2 shows that, Village Cundui has a number of donkeys, decreasing from 180 in 1984 to 96 now, and Village Chabalang has no donkey at present, with 30 in 1984. The number of donkeys in Village Zhaxilin has decreased from 500 in 1984 to 2 now, and the 2 donkeys are in advanced age and cannot work any longer. Taking everything into consideration, the main reason for the dramatic decline of donkey numbers in the above villages could be summarized as follows:

- The need to keep donkey as transport tool did not exist any more.

After 1984, farmers became the main body of Tibetan rural management, and the central government exempted Tibetan farming-pastoral areas from tax as well, thus Tibetan farmers became the first who needn't hand in grains to the government in China. Donkeys successfully completed their grain-transporting task.

- Change of ecological environment and the government's environmental protection policies have reduced farmer's reliance on donkeys for firewood.

From the historical point of view, firewood in Tibetan farming-pastoral areas was mainly obtained through livestock dejecta, along with branches of thorns, Chamaecyparis obtuse, capitate rhododendron branchlet and leaf, as well as pine and cypress. In the middle 1980s, the reform of Tibet not only improved farmers' living conditions but also created relaxing religious atmosphere for farmers. The better life people had, the more hulless barley, chang and "sang" were needed, which required more firewood. During the 1980s and middle 1990s, the public did not fully understand the importance of environment protection, nor did the government take effective measures to protect plants. So farmers, more frequently, cut more firewood on a larger scale. In the early 1990s, when the number of donkeys in these 3 communities remained the same as in 1984, farmers' firewood piled on walls was not branches, but the roots of thorns and bushes.

In the mid 1990s, owing to constant cutting, thorns and bushes in Village Zhaxilin, Village Chabalang, and Village Cundui were nearly exhausted. Faced with resource exhaustion and environmental deterioration, the government took more action for environmental protection and stopped farmers from cutting plants. In the meantime, solar furnace became popular in Tibet, and $80 \%$ farmers began to use one provided by the government, and some wealthy farmers began to use natural gas stove. All these enabled farmers to be less dependent on firewood, which in turn weakened the status and role of donkeys, the help for farmers to convey firewood.

Since 2000, global warming has become aggravated. When we entered the above communities again, farmers often talked about drought caused by shortened raining seasons and declining rainfall. A case in point is: except Village Lunbugang, the mountains in the other 3 communities used to be full of green trees in early July. But after 2000, this time delayed to late July or even early August. Drought and high temperature greatly affected the growth of grass to such an extent that for most time during a year, farmers of Village Zhaxilin and Village Chabalang had to operate animal husbandry by enclosing livestock, which led open animal husbandry to a precarious situation. The condition of Village Zhaxilin was especially worrying. Between 2009 and June to July, 2010, because of lack of fodder, many farmers fed their livestock by collecting leaves, and some farmers even sold their cows. The scarcity of grass forced farmers to change the size and structure of livestock-keeping
(Luorong Zhandui 罗线战堆, 2002). One of the agonizing decisions made by farmers in most Tibetan areas was to abandon donkeys.

With the increase of income and selling spots of natural gas, together with exhausting firewood and the official ban, a rising number of wealthy farmers began to use natural gas instead of firewood, and its proportion rose sharply after 2000 (see Table 3). Additionally, since 2005, in order to protect environment and solve the energy shortage of Tibetan rural areas, governments at different levels of Tibet set out to build marsh gas tanks and provided free burners burners free of charge. In 2010, in the above 4 communities, $50 \%, 60 \%, 30 \%$ and $40 \%$, respectively, farmers used marsh gas. Now, many farmers in Tibet own "tuzao" and "ganglu” as well as solar furnaces and marsh gas furnaces given by the government or natural gas furnaces bought by themselves. What is more, in the past two years, the government has built blast-equipped public furnaces for the purpose of frying hulless barley, for which dairy manure and straw can be used as fuels. Tibetan farmers using 5 different kinds of furnaces should, if ever, be included in Guinness. may even set a world record.

A recent survey shows that efforts by farmers and the government have decreased the consumption of firewood by $70 \%$ $80 \%$ in Village Zhaxilin and Village Chabalang. Furthermore, thorns and bushes tend to be exhausted in these 2 villages, so firewood especially materials for "weisang" have to be purchased from the market. Thus, in these two communities, donkeys have thoroughly completed their mission to help farmers convey firewood. There are no donkeys in Village Chabalang, and there are only 2 old donkeys in village Zhaxilin.

However, in Village Cundui, there are still 96 donkeys used. According to a survey, the firewood substitution is significant in this village, and the consumption of firewood per household has decreased by $60 \%$ - 70\%. Compared with Village Zhaxilin and Village Chabalang, farmers in this village still needed to cut firewood. Villagers said that there are some thorns and bushes in distant mountainous areas. In spite of the official ban, many farmers still ride donkeys secretly to cut firewood in the evening, Therefore, donkeys still play a part in carrying firewood, which is perhaps an important reason why there are still some donkey remained in this village.

- The function of donkeys in agriculture is gradually being replaced by machinery.

In the past, with poor infrastructure, producing and living conditions, donkeys were an important help to farmers. However, with the construction of roads in Tibet and improvement of rural living conditions, farmers have had strong passion for buying machines. A questionnaire of the 4 communities made in 1998 showed that tractors, female yaks and new houses ranked the top three on the list of farmers' investment. The

Table 3.

Proportion of natural gas furnaces used by farmers in 4 communities in 1995, 2005 and 2010.

\begin{tabular}{ccccc}
\hline Year & $\begin{array}{c}\text { Village } \\
\text { Zhaxilin }\end{array}$ & $\begin{array}{c}\text { Village } \\
\text { Chabalang }\end{array}$ & $\begin{array}{c}\text { Village } \\
\text { Cundui }\end{array}$ & $\begin{array}{c}\text { Village } \\
\text { Lunbugang }\end{array}$ \\
\hline 1995 & $5 \%$ & $8 \%$ & $6 \%$ & $0 \%$ \\
2005 & $20 \%$ & $30 \%$ & $25 \%$ & $10 \%$ \\
2010 & $70 \%$ & $90 \%$ & $86 \%$ & $50 \%$ \\
\hline
\end{tabular}

Note: Source: the authors field work in 1996, 2005 and 2010. 
rapid increase in machinery in different communities also proved that many farmers had realized their dreams (see Table 4).

According to the above statistics, in order to exclude the effect of normal growth in population and households on the increase of machinery, average number of machines owned by the households in 1984 and 2010 should be taken into account (Table 5).

Through comparison we can see that in 1984 only 14 households owned one tractor and 36 households owned one car, adding machine and grain blower, it would be very difficult for farmers to deal with agricultural and other activities without a certain number of donkeys. Nowadays, every household owns one tractor and the number of other machines also has risen drastically, therefore donkey's role has been reduced when farmers begin to use machines rather than donkeys. Thus, donkeys' function as a help of farmers has been greatly weakened, and they are bound to be abandoned.

\section{How Farmers Face Culture Shock in Donkey Abandonment}

In Tibet, donkeys is considered the model of diligence, also an important help in various activities even family members. Because of religious and cultural factors, Tibetan farmers never kill donkeys and horses for food. Instead, they feed donkeys and give proper burial upon death. But with the rapid economic development and deepening environmental factors, the historical status and function of donkeys are challenged. It seems not economical and necessary to raise donkeys, so they will be abandoned unavoidably, though farmers may suffer from agony.

The word "Agony" is used to show how farmers feel when they have to abandon their donkeys, because even though farmers have to abandon them, they do not have proper ways to do that. If they want to discard donkeys, they either kill them or present them or sell them. The traditional culture forbids the killing (Garma Jangtsun 噶玛降村, 2005). If they present or sell them to local farmers, nobody needs or buys them. If they present or sell them to other people, they are afraid that donkeys will be killed, which will lead to shame and provoke neighbors' criticism. However, different districts in Tibet develop at different rates. If one district does not use donkeys, another district will probably use them. On the other hand, China has large territory, and cultural differences between Tibet and internal areas are obvious. People in Tibet do not eat donkeys, but people in other areas do not mind or may even enjoy eating donkey. In many areas of Han nationality, donkey meat is regarded as a delicacy, as an old Chinese saying puts, "dragon meat in the heaven and donkey meat on earth". The other 3 communities except Village Lunbugang, have their way to abandon donkeys and cope with traditional culture and customs.

Village Chabalang is the community with the fewest donkeys, the first to abandon them and the most complete one. In 1984, farmers owned only 30 donkeys from people's communes. Located near Lhasa, this village had convenient transport, and its productivity and living conditions ranked the first among the 4 communities. Since the 1990s, farmers in this village have begun to buy tractors and abandon donkeys. Within 10 years, donkeys disappeared in this village. But as to the abandoning methods, different people had different ideas.

The old village leader told us that the main method was selling them to poor communities in Shigatse via Tibetan livestock dealers, with 50 - 80 Yuan per donkey, while another young leader, after drinking, said that the first 10 donkeys were sold to farmers in Shigatse at a low price. After this, some livestock dealers of Muslim nationality came, offering 150 yuan for one

Table 4.

Statistics of machines used in 4 communities in 1984 and 2010.

\begin{tabular}{ccccccccc}
\hline Village & Year & Households & Tractors & Cars & Seeders & Reapers & Grain Blowers & Motor cycles \\
\hline \multirow{2}{*}{ Zhaxilin } & 1984 & 70 & 3 & & & & 4 & 0 \\
& 2010 & 83 & 7 & 5 & 4 & & 7 & 6 \\
Chabalang & 1984 & 60 & 3 & & 3 & & 2 & 0 \\
& 2010 & 105 & 120 & 30 & 60 & 60 & 3 & 8 \\
Cundui & 1984 & 90 & 12 & 2 & 3 & & & 0 \\
& 2010 & 102 & 110 & 3 & 20 & 1 & & 0 \\
Lunbugang & 1984 & 33 & & & 1 & & 1 & 25 \\
Total & 2010 & 47 & 30 & & 3 & 2 & 2 & 7 \\
Total & 1984 & 253 & 18 & 7 & 7 & 0 & 12 & 0 \\
\hline
\end{tabular}

Note: Source: data from field work by the authors in 1984 and 2010.

Table 5.

Average machine per household in 1984 and 2010.

\begin{tabular}{ccccccc}
\hline Year & Tractors & Cars & Seeders & Reapers & Grain Blowers & Motorcycles \\
\hline 1984 & 14 & 36 & 36 & none & 36 & none \\
2010 & 1.26 & 8.8 & 3.8 & 5.3 & 28 & 2.5 \\
\hline
\end{tabular}

Note: Source: data from field survey by the authors in 1984 and 2010. 
donkey and promising not to kill the donkeys, eat or sell donkey meat, but to send. Some farmers believed this, and sold about 10 donkeys to these dealers. But soon they heard from Lhasa that the sold donkeys had been killed in a cruel way. Many villagers thought this harmed the traditional culture and customs in Tibet (Kelzang Yeshe 康•格桑益希, 2003). From then on, livestock dealers of Han and Muslim nationalities were rejected. These dealers soon changed their practice, employing Tibetans especially Kham people to purchase donkeys in farming-pastoral areas, while they themselves would wait by the road far away from the village. The last 10 donkeys were eliminated in this way.

Village Zhaxilin is the community with the most donkeys in the history, and its way of abandoning donkeys was almost the same as Village Chabalang: a small number of donkeys were sold to Tibetan farmers in Shigatse, and others were sold to dealers of Han and Muslim nationalities who were willing to offer higher prices. There were many people in this village and nearby villages who dealt with Tibet wool, and selling donkeys to Han and Muslim dealers could not be kept as a secret. This village is sited in deep mountains lined by many villages all the way, so any trade in or near the village will easily attract others' attention and words spread quickly. In order to overcome the obstacle of the traditional culture to the trade, farmers generally make an appointment with Tibetans employed by Han and Muslim dealers and make a deal at a concealed spot. However, there are two households in this village who, facing the reality that forage is scarce and donkeys cannot work any longer, persist in their own traditional culture (Lorja Tsering 洛加才让, 2002) by protecting the donkeys' right to live.

There are still a few donkeys in Village Cundui, because in this village donkeys can still be used. Owing to the geographical condition, it is not very convenient to send donkeys to other Tibetan communities. Villagers mainly depend on livestock dealers from outside, especially dealers of Muslim nationality. Although there are many businessmen in Lhvnzhub county town, including livestock dealers, some dealers resell Tibetan women and pay with forged banknotes, which contaminate their own reputation, and thus causing Tibetans' resistance to businessmen of Muslim nationality. When 3.14 Event in 2008 took place, a few Tibetan people even broke into business facilities of Muslim nationality in county town. Up to now, few businesses have recovered their business. Under this circumstance, Tibetan farmers face bigger cultural obstacles if they trade with Muslim dealers.

\section{Summary}

- There are many reasons that the number of donkeys in the above communities has sharply decreased during the past 25 years, but the most important one lies in degeneration of environment. As many farmers observed during the interview, if there were enough forage in the nearby mountains, they would keep donkeys free. But when forage is so scarce even for cows they have no choice but to abandon donkeys.

- There are many reasons for environmental degeneration, among which too many livestock and long-term over-cutting of plants are the two major ones. Even now, although the government tries to protect the environment by administrative, economic and technological approaches, and implements the official ban on cutting and provides firewood substitution, there are other difficulties. For one thing, farmers must raise some livestock to earn their living, so it is hard for the government to interfere. Another reason is that farmers have to do "weisang" for their religious belief, for which they have to cut firewood from mountains and nothing could substitute it. If the government interferes, it is possible to bring about a blame for "not respecting religion" of farmers and international communities. Thus, Tibetan environmental degeneration in population centers will continue.

- Development of economy is bound to cause the change of culture, especially the traditional culture, which should act of its own accord. But without economic development, people will lack economic deposits, and adherence to the traditional culture will be a mere façade. Villagers of Lunbugang do not eat fish now, and villagers of Cundui cherish the black-necked crane perching there with seasons; however, between 1960s and 1970s, with poor living conditions, villagers often exploded fish with caught and killed cranes with woduo, and cooked them for food. Therefore, development is not the only factor leading to environmental change; poverty can play a part as well.

- After reform and opening-up, the development and change of Tibetan rural areas, especially the improvement of producing and living conditions, have been impressive. But with the development of economy and deepening of opening to the outside world, as more and more people, with different cultural background and religious belief, come to Tibet for various business activities, clashes and conflicts are inevitable because of their culture shock and conflicting interests. The government has a long way to solve these problems.

\section{REFERENCES}

Garma Jangtsun 噶玛降村 (2005). Zangzu Chuantong Wenhua zhongde Shengtaiguan 藏族传统文化中的生态观. Journal of Kangding Normal College for Nationalities, 2, 12-16.

Kelzang Yeshe 康・格桑益希 (2003). “Benjiao”-Zangzu chuantong wenhua de yuantou “苯教” ——藏族传统文化的源头. Journal of Sichuan University, 5, 59-62.

Lorja Tsering 洛加才让 (2002). Zangzu shengtai lunli wenhua chutan 藏族生态伦理文化初探. Journal of the Northwest College for Nationalities, 5, 35-38.

Luorong Zhandui 罗线战堆 (2006). Xizang chongcaoziyuan jiqidui nongmumin shouru yingxiang de yanjiubaogao 西藏虫草资源及其 对农牧民收入影响的研究报告. China Tibetology, 2, 102-107.

Luorong Zhandui 罗线战堆 (2009). ZangzuDiqu “xishaxishou” wentiyanjiu 藏族地区 “惜杀惜售” 问题的研究. Journal of Southwest University for Nationalities, 11, 13-17.

Luorong Zhandui 罗线战堆 (1996). Qingzang xumuye bijiao yanjiu 青藏畜牧业比较研究. China Tibetology, 4, 31-42.

Luorong Zhandui 罗线战堆 (2002). Xibu kaifa yu xizang de kechixufazhan 西部开发与西藏的可持续发展. Beijing: China Tibetology Publishing House.

Nan Wenyuan 南文渊 (2008). Zangzu chuantong wenhua yu qingzanggaoyuan huanjing baohu he shehui fazhan 藏族传统文化与青 藏高原环境保护和社会发展. Beijing: China Tibetology Publishing House.

Tsering Dundrup 得荣・泽仁邓珠 (2005). Zangminzu chuantong xinyang yu shengtaihuanjing de baohu 藏民族传统信仰与生态环 境的保护. China Tibetology, 2, 44-47. 